\title{
CYTATY Z PRZESZŁOŚCI - RYTY NA DRZEWACH W PRZYPAŁACOWYM PARKU W NAKLE (GMINA LELÓW). ODCZYTYWANIE NIEOCZYWISTYCH ELEMENTÓW LOKALNEJ HISTORII
}

SŁowa KLuczowe: pałac w Nakle, ryty na drzewach, miejsce, lokalne narracje, lokalna historia

Keywords: Nakło Palace, carvings on trees, place, local narratives, local history

\section{MiejSCE W KRAJObRAZIE}

Co odróżnia osiedle, osadę, ulicę, dom od innych fragmentów krajobrazu wokół? Zapewne jednym tchem wymienimy: fizyczna lokalizacja i otoczenie, działania i funkcje oraz wartości i symbole - elementy nieredukowalne, składające się na „obraz” doświadczany całościowo i często nieświadomie. Fragmenty krajobrazu - miejsca - mają zdolność nadawania znaczeń. Są rozpoznawalne i nieobojętne. Mentalne mapy miejsc, noszone w pamięci, rozpisane są na najdrobniejsze szczegóły (odległości, skróty), są narzędziem władzy i wiedzy, presupozycji obserwatora i efektem kulturowych praktyk.

Każde miejsce ma też rozciągniętą w czasie historię, rekonstruowaną często we fragmentach, pełną przeskoków, zmian w sposobach postrzegania i określenia charakteru przestrzeni. Biografie te rządzą się jednak swoimi prawami - różnymi od praw historycznego, naukowego poznania i historycznej, naukowej narracji. Utkane są bowiem z wydarzeń odnotowanych na kartach tak zwanej oficjalnej historii, zmieszanych ze wspomnieniami, emocjami i osobistymi doświadczeniami, opowiadającymi o sposobach organizowania, doświadczania i waloryzowania wybranych elementów krajobrazu.

Oto przykład miejsca wpisanego w fizyczny i kulturowy krajobraz gminy Lelów, na północnych terenach Jury Krakowsko-Częstochowskiej. Miejsca 
ważnego - jak wynika z przeprowadzonych badań etnograficznych i zebranych narracji - dla lokalnej społeczności; obecnego w opowieściach i w pamięci wspólnoty ${ }^{1}$.

\section{Zespól palacowo-Parkowy. Historia lokalna}

Tuż przy wschodniej granicy województwa śląskiego, w powiecie częstochowskim, pomiędzy Szczekocinami i Lelowem, znajduje się wieś Nakło. Miejscowość, położona w strefie przejściowej pomiędzy Progiem Lelowskim i Niecką Włoszczowską, swoją toponimię zawdzięcza prawdopodobnie założycielom - rodowi Nakiel - pierwotnie określana tą właśnie odimienną nazwą. Istniała przypuszczalnie już w drugiej połowie XII w. W drugiej połowie XVIII stulecia właścicielami ówczesnego miasteczka (prawa miejskie utracone w 1825 roku) byli niejacy Młodzianowscy. Dzięki ożenkowi z Marcyanną Młodzianowską, dziedzicem nakielskich dóbr został hrabia Kajetan Bystrzanowski. Postanowił on wybudować pałac, który mógł pomieścić wszystkich gości świeżo mianowanego sędziego w Trybunale Koronnym (Matysiak 2003). I tak, w latach 1770-1780, na podstawie projektu autorstwa znanego architekta - Jana Ferdynanda Naxa, w Nakle powstał okazały pałac w stylu barokowo-klasycystycznym. Trójkondygnacyjny, dziewięcioosiowy budynek na rzucie prostokąta, przykryty dachem mansardowym z lukarnami otoczony został sadami i rozległym parkiem, w którym dziś odnaleźć można między innymi pomnikowe okazy lipy drobnolistnej, buka zwyczajnego i derenia jadalnego (Rejestr zabytków nieruchomych woj. śląskiego...).

Kompleks pałacowy (obiekt główny i m.in. dawne budynki gospodarcze) wraz z rozplanowanym terenem zadrzewionym o powierzchni blisko 3 ha położony jest w południowej części Nakła (ryc. 1). Jeszcze w pierwszej połowie XX w. założenie parkowo-pałacowe wyznaczało południową granicę zabudowań miejscowości. Otoczone jest charakterystycznym, zaświadczającym o średniowiecznych początkach miejscowości, niwowym układem pól, których podział, z uwagi na powiększającą się liczbę gospodarstw, ulegał stopniowemu rozdrobnieniu. W miejscu wystawienia pałacu znajdowała się wcześniej siedziba dworska, być może o proweniencji XV-wiecznej, wymieniana w źródłach ówczesnych dziedziców Nakła - Jakubików (Jakubikonem)

${ }^{1}$ Tekst powstał na podstawie badań i z wykorzystaniem materiałów zebranych podczas realizacji projektu Miejsca pamięci i zapomnienia. Badania interdyscyplinarne pótnocnych terenów Jury Krakowsko-Częstochowskiej. Projekt realizowany w ramach Narodowego Programu Rozwoju Humanistyki, w latach 2014-2019, na terenie 5 gmin powiatu częstochowskiego: Janów, Mstów, Lelów, Olsztyn, Przyrów. Więcej informacji na temat badań można znaleźć na oficjalnej stronie projektu: najurze.uni.lodz.pl. 


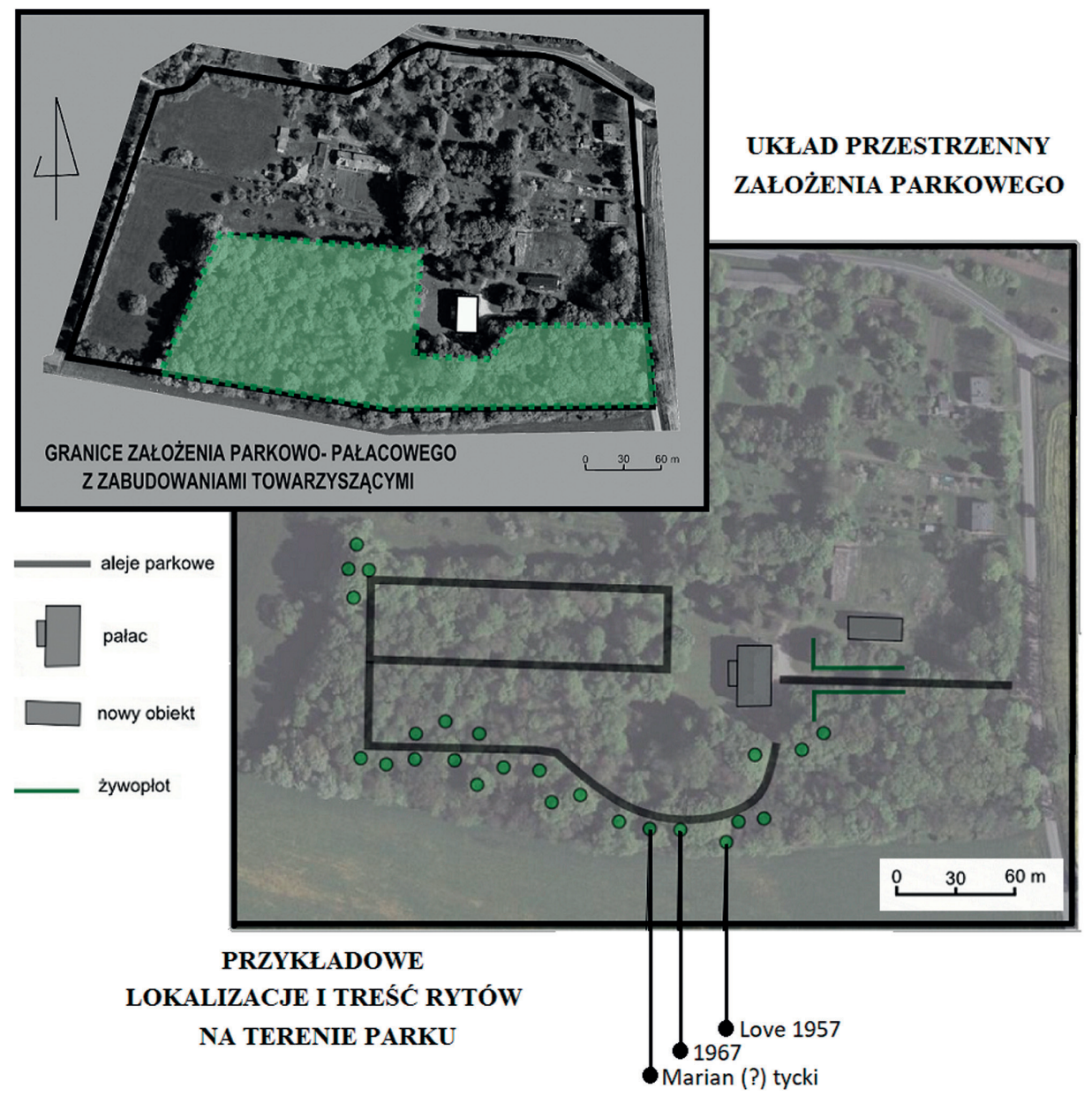

Ryc. 1. Założenie parkowo-pałacowe w Nakle - układ przestrzenny (oprac. Anna Majewska).

i Pradontów (Pradontha), a później Otfinowskich (XVI w.), Stradomskich (XVII w.) i Młodzianowskich (XVIII w.). W ciągu wieków więc założenie z dworsko-folwarcznego ewoluowało do formy parkowo-pałacowej, której główne składowe są zachowane do dzisiaj.

Po śmierci Kajetana Bystrzanowskiego majątek odziedziczył syn hrabiego - Józef. Możemy o nim przeczytać w kronice O starej wsi Nakło i wspótczesnym jej rozwoju. Autorem tego niepublikowanego dotąd dokumentu, przekazy- 
wanego $\mathrm{w}$ formie kopii $\mathrm{z}$ rąk do rąk pasjonatów lokalnej historii, trzymanego w domowych archiwach, jest mieszkaniec Nakła - Stanisław Trela. Pisze on, że (Trela 2005: 7):

Właściciel dóbr hr. Józef Bystrzanowski był człowiekiem szlachetnym i wrażliwym na niedolę ludzi starych, bezdomnych i osieroconych dzieci. Przed śmiercią sporządził testament, w którym przeznaczył 300 rubli jako kapitał stały z oprocentowaniem wpisany do hipoteki i zobowiązał swoich spadkobierców do wystawienia dla ludzi bezdomnych i osieroconych dzieci pozbawionych opieki domu schronienia.

W następnych dziesięcioleciach gospodarze majątku często się zmieniali. Około 1839 roku dobra przejął Michał Zbijewski, żonaty z córką Bystrzanowskiego - Teresą. W kronice S. Treli (2005: 9) czytamy:

Dziedzic rozległych dóbr Michał Zbijewski poza dochodami z gospodarstw rolnych, zabiegał o zyski z innych źródeł. Rozpoczął budowę obiektów rzemieślniczych i handlowych. W Nakle wybudował warsztat kowalski i stolarski, gdzie wykonywano na zamówienie właścicieli majątków różnego rodzaju bryczki, powozy i karety. Wykorzystując dogodne położenie na szlaku komunikacyjnym wsi Nakło, wybudował w środku wsi na obszernym placu tuż przy głównej drodze, obszerny dom zajezdny, w którym znajdowało się kilka różnych pomieszczeń, jak np. pokoje noclegowe, lokal na karczmę, mieszkanie dla obsługi, stajnie dla koni i pomieszczenia na pojazdy. Po drugiej stronie drogi w budynku już istniejącym urządził piekarnię, która dostarczała pieczywo dla karczmy i pałacu. W odległości około $2 \mathrm{~km}$ od wsi w kierunku zachodnim, w pobliżu lasu znajdował się duży obszar pastwisk, a na nim obszerny budynek - owczarnia dla hodowli owiec. Kilka rodzin użytkujących niewielkie obszary ziemi ornej było zatrudnionych przy hodowli kilkuset sztuk owiec. Michał Zbijewski jako dobry, z wyższym wykształceniem dziedzic, był przez ogół szlachty ceniony i poważany, dlatego często go odwiedzano. Okazją do spotkań były urządzane w sezonie jesienno-zimowym polowania na zwierzynę łowną, na które licznie przyjeżdżali jego znajomi właściciele majątków. [...] Właściciel dóbr Michał Zbijewski wymagał od zatrudnionych ludzi dużego wysiłku w pracy. Za zaniedbania i różne przewinienia karał. Niekiedy winnych wzywał do pałacu, gdzie obok kancelarii, w małym pokoiku, wymierzał karę cielesną.

Zbijewscy byli także właścicielami działającego w Nakle młyna wodnego, tartaku, cegielni, a nawet gorzelni. Cały ten majątek przejął wkrótce ich syn - Jan. Mało jednak interesował się nakielskimi dobrami. Często przebywał za granicą, w Paryżu. Majątek przestał przynosić satysfakcjonujące go dochody, postanowił więc go sprzedać (Matysiak 2003). Informację o nowych właścicielach znów znajdujemy u nakielskiego kronikarza, który donosi, że (Trela 2005: 12): 
Nabywcą został w 1899 r. Władysław Hencel, pochodzący z Litwy. W 1904 r. hr. Mohl z pochodzenia Anglik, pojął za żonę córkę Wł. Hencla i osiadł w Nakle $\mathrm{z}$ tytułem dziedzica dóbr. W następnym roku, po przejęciu majątku, przystąpił do budowy krochmalni, którą zakończono w 1906 r. W sezonie jesienno-zimowym przerabiano w niej ziemniaki na krochmal.

Po śmierci hrabiego Mohla w 1911 roku majątek nabyli bracia Borkowscy, ale po kilku latach odsprzedali go Michałowi hrabiemu Komorowskiemu, wnukowi Michała Zbijewskiego.

Do początków XX wieku sięga pamięć dzisiejszych mieszkańców Nakła. Funkcjonowanie posiadłości wiązało się ze złożoną organizacją pracy i zaangażowaniem wielu osób. Z historią pałacu w Nakle splecione są więc rodzinne biografie mieszkańców wsi. Majątek wraz z zabudowaniami gospodarskimi i całą infrastrukturą nie tylko dominował w okolicznym krajobrazie, ale był także miejscem zarobku dla lokalnej, a często i przyjezdnej ludności, co wpływało tym samym na organizację jej życia codziennego. Starsi mieszkańcy wciąż pamiętają, co mieściło się w poszczególnych budynkach wchodzących w skład posiadłości². Wiedzą, gdzie stała studnia, z której brano wodę do pojenia hrabiowskich koni. Wspominają, że do dojenia krów, najęte były cztery kobiety. Opowiadają, jak w stodole, pod trocinami, trzymane były wielkie bryły lodu, którymi później obkładano - dla zachowania świeżości - bańki z mlekiem, zawożone przez chłopa nazwiskiem Chruściel do Koniecpola i Sędziszowa.

W pamięci nakielan zapisał się też czas II wojny światowej. S. Trela w swoich notatkach odnotowuje informację z pierwszych dni września (2005: 20-22):

Pożar 3 września 1939 roku. W tragicznej sytuacji znalazły się rodziny w Nakle, które straciły w pożarze domy wraz z urządzeniem, część zwierząt hodowlanych i narzędzia rolnicze. Bardzo duże trudności były z zakwaterowaniem nieszczęśliwych ludzi pozbawionych mieszkań, gdyż znaczna część pozostałych domów były jednoizbowe. Kilkanaście rodzin znalazło schronienie w dwóch budynkach szkolnych. [...] W takich warunkach lokalowych nie mogły się odbywać normalne zajęcia dla młodzieży szkolnej. [...] Kierownik szkoły Franciszek Lipowski prosił właściciela majątku ziemskiego Michała Komorowskiego o bezpłatne wynajęcie dla szkoły trzech pokoi w miejscowym pałacu. Właściciel majątku chętnie oddał w użytkowanie dla szkoły trzy pokoje na sale lekcyjne do czasu opróżnienia budynków szkolnych przez zamieszkujące, bezdomne rodziny.

W innym miejscu tego samego opracowania czytamy o kolejnym epizodzie związanym z nakielskim pałacem (Trela 2005: 28).

\footnotetext{
${ }^{2}$ Nagrania i transkrypcje wywiadów etnograficznych znajdują się w archiwum projektu Miejsca pamięci i zapomnienia. Badania interdyscyplinarne pólnocnych terenów Jury Krakowsko-Częstochowskiej.
} 
Kiedy front dotarł do Wisły, dowództwo armii hitlerowskiej rozpoczęło przygotowanie umocnień nad rzeką Pilicą. W tym celu w sierpniu 1944 r. przyjechał do Nakła liczny oddział niemiecki i zakwaterował się w miejscowej szkole i w pałacu. Codziennie pod rygorem wojskowym zabierali ludzi ze wsi do budowy okopów, schronów i rowów przeciwczołgowych wzdłuż lewego brzegu Pilicy.

Mieszkańcy opowiadają też, że podczas wojny, w pałacu, pod przykrywką siedziby nadleśnictwa, odbywały się tajne komplety nauczania oraz że funkcjonował tam sztab gminny Armii Krajowej; że pod dębową, pałacową podłogą przechowywana była broń. Szefem sztabu miał być inżynier Piotr Stolarski, który spisał swe wspomnienia - wciąż przechowywane przez jego mieszkającą w Nakle rodzinę.

O P. Stolarskim można również przeczytać w jednym z wpisów złożonych w księdze gości, która czeka dzisiaj na odwiedzających pałac:

Nakło 26 kwietnia 2015 roku.

Byłem tutaj jako pacholę i dziecko w latach 1939 (wrzesień) - 1945 (lato). Ojciec mój Piotr Stolarski został zatrudniony przez hr. Komorowskiego (z siedliska) jako leśniczy w jego dobrach. Mieszkaliśmy najpierw w pałacu, później w czworaku. Ojciec był dowódcą placówki AK. Jego siedziba w pałacu. Z tamtych czasów pamiętam dość sporo. Ogród warzywny przed czworakami, pompę ręczną, przy której myli się Niemcy. Poddasze pałacu olbrzymie, gdzie p. Starowiejska suszyła zioła. Pamiętam ziemną piwniczkę z bryłami lodu, z trocinami. Pamiętam wojskowe lotnisko Rosjan na polu tuż za parkiem w kierunku Szczekocin. Także zapach samolotów, tamtej benzyny i amunicji. Pamiętam bramę wjazdową od strony drogi do siedliska z wnękami posągowymi w słupach bramnych.

Jestem pełen podziwu dla obecnych właścicieli, którzy na pewno wkładają dużo serca, a przede wszystkim pieniędzy, by to piękne założenie pałacowo-parkowe doprowadzić do pierwotnego stanu.

Serdecznie pozdrawiam i życzę powodzenia, Dobromiła i Lech Stolarscy ${ }^{3}$.

Komorowscy zarządzali majątkiem do zakończenia II wojny światowej, potem utracili go na rzecz państwa. W pałacu utworzono szkołę rolniczą, a kilka lat później, w 1956 roku, zorganizowano w nim Państwowy Dom Dziecka w Nakle. Trela opisuje, że (2005: 42):

W celu dostosowania do potrzeb przejętych budynków: pałacu, dawnej oficyny i dwóch budynków gospodarczych, przeprowadzony został wewnętrzny remont, zmiana pokrycia przeciekającego dachu i kanalizacja pałacu. W pozostałych budyn-

${ }^{3}$ Kopia wpisu znajduje się w archiwum projektu Miejsca pamięci i zapomnienia. Badania interdyscyplinarne pólnocnych terenów Jury Krakowsko-Częstochowskiej. 
kach dokonano wewnętrznej przebudowy, na jednym dobudowano piętro i urządzono pomieszczenia na kancelarię, przedszkole i mieszkania dla wychowawców oraz pracowników zatrudnionych w Domu Dziecka.

„,8 października 1955 roku przybyło tu osiemnastu wychowanków i pięciu pracowników. Najwięcej w Domu Dziecka było 62 wychowanków, z czego 9 dzieci przedszkolnych" (Matysiak 2003). Mieszkańcy opowiadają, że w ramach eksperymentu władze oświatowe zorganizowały przy Domu Dziecka tak zwane gospodarstwo pomocnicze, w którym większość prac wykonywali wychowankowie. Wspominają, że przez jakiś czas przy placówce funkcjonowała szkoła podstawowa, starsze dzieci wysyłane były zaś do szkół oraz internatów w Tychach i Sosnowcu. Ten rozdział historii nakielskiego pałacu zakończył się 2 października 1989 roku.

W 2002 roku zespół pałacowo-parkowy zakupili Marzenna i Kehrt Reyherowie, stając się trzecimi od 1989 roku prywatnymi właścicielami majątku. Małżeństwo powołało Fundację Nakielską, która za cel obrała restaurację pałacu oraz sprawowanie pieczy nad obiektem, pełniącym od tamtej pory funkcję turystyczno-noclegową. Na oficjalniej stronie internetowej prowadzonej przez właścicieli czytamy (http://naklopalace.org/pl):

W naszym pałacu trudno mówić o ,zakwaterowaniu”. W miejscach magicznych gości nie kwateruje się tak po prostu. Wprowadza się ich „na pokoje” i zapewnia doświadczenia, które są na co dzień dla większości niedostępne. Nie ze względu na przepych - styl pałacu w żadnym wypadku nie jest ,,barokowy”, raczej czarująco sielski i komfortowy - ale ze względu na przestrzeń do oddychania wewnątrz i otoczenie zewnętrzne.

Pałac nakielski to turystyka wiejska z klasą i długą, sięgającą drugiej połowy 18. wieku historią $\mathrm{w}$ tle a ponadto $\mathrm{z}$ wyjątkową atmosferą, którą może zapewnić jedynie wrażliwe na innych i na piękno przedsięwzięcie rodzinne.

W pałacu, w którym na parterze mieszkają gospodarze, są dostępne cztery apartamenty. Dzięki ich ponadstandardowym rozmiarom, liczba gości jest elastyczna, ale nigdy nie przytłaczająca. W ten sposób zapewniamy prywatność i możliwość kontaktu $\mathrm{z}$ innymi na własnych warunkach. [...]

Wszystkie apartamenty znajdują się na pierwszym piętrze i dzięki dużym, przesłoniętym jedynie cienkim muślinem oknom mają doskonały widok na urokliwe otoczenie pałacu w tym parkowy starodrzew. Pokoje układają się wokół centralnego salonu o powierzchni $63 \mathrm{~m}$. kw., który spełnia funkcję przede wszystkim centrum rozrywkowego.

Remont pałacu w Nakle rozpoczął się w 2004 roku i trwa nadal. Kiedy Reyherowie zakupili posiadłość, jej stan wymagał nie tylko prac renowacyjnych i naprawczych, ale gruntownych działań ratujących lub odbudowujących 


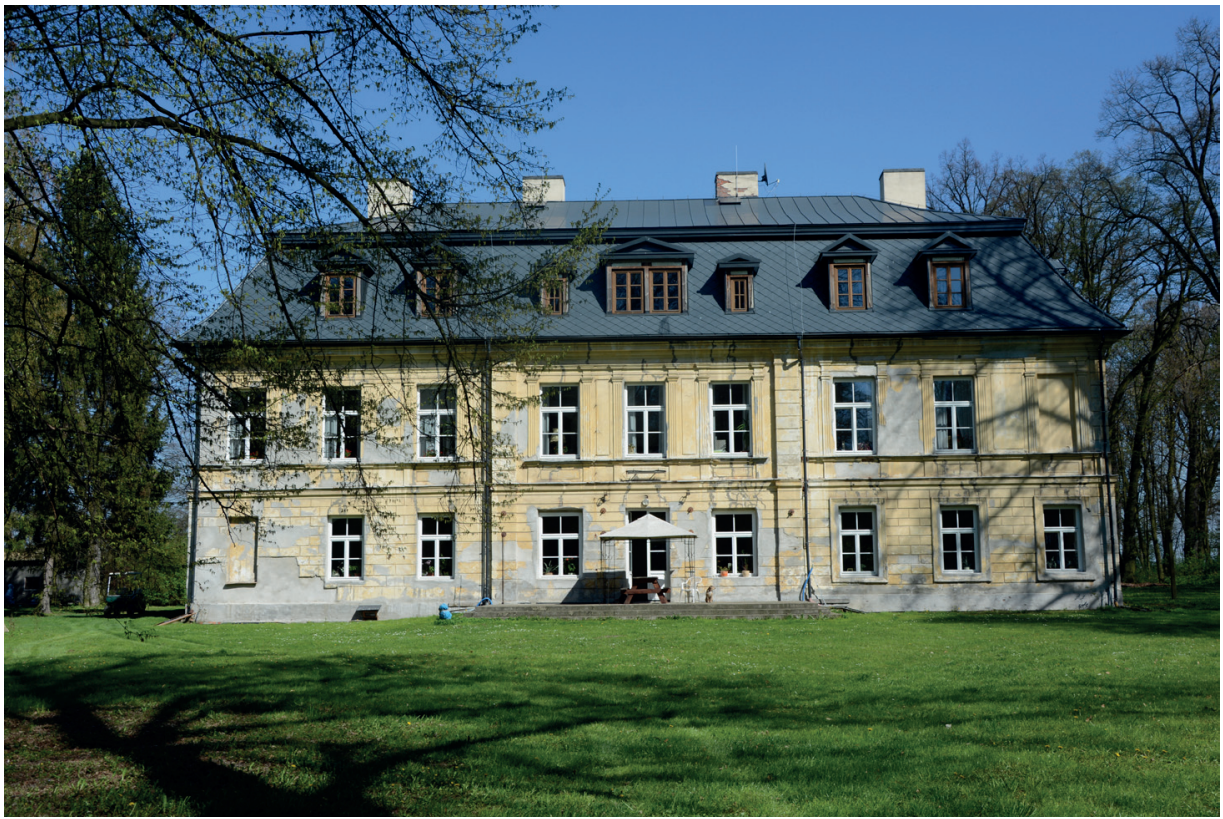

Ryc. 2. Widok na pałac od strony parku (fot. Aleksandra Krupa-Ławrynowicz, 2016).

niektóre części zabudowań. Położono nowy dach, osuszono ściany, wymieniono wszystkie instalacje, wzmocniono stropy. Trzy lata czekano z malowaniem aż budynek wyschnie po przeprowadzonej hydroizolacji (ryc. 2).

Celem prowadzonej przez właścicieli fundacji jest, oprócz odbudowy zespołu pałacowego, także wspieranie miejscowych potrzeb. Fundacja organizuje wieczory kulturalno-artystyczne, partycypuje jako sponsor w gminnych imprezach. W przypałacowym parku rozgrywany jest cykliczny Turniej w Rzucie Podkową o Puchar Wójta Gminy Lelów, zaś w salonie odbywają się koncerty i spotkania dedykowane okolicznej społeczności. Zapis w statusie fundacji mówi, iż powinna ona wspierać lokalną przedsiębiorczość, rozwój turystyki, upowszechniać lokalne przedsięwzięcia kulturalne i naukowe, promować region nakielski w świadomości społecznej, inicjować i wspomagać działania na rzecz ochrony środowiska naturalnego, w szczególności ochrony środowiska naturalnego regionu nakielskiego.

Od początku istnienia pałacu, także dzisiaj, po trzystu niespełna latach, splatają się codzienne ścieżki jego właścicieli i mieszkańców wsi. Nakielska posiadłość wciąż jest miejscem wyrazistym i znaczącym - zarówno w topografii okolicy jak i w życiu lokalnej społeczności. 


\section{RYTY NA DRZEWACH - REMINISCENCJA PRZESZLOŚCI}

W miejscu posiadającym kilkusetletnią ciągłość osadniczą, związaną z zamieszkaniem kolejnych rodów dziedziców miejscowości, a później prywatnych właścicieli nakielskiej posiadłości, znajduje się park, swoją genezą sięgający prawdopodobnie XVIII w., czyli początków rezydencji Bystrzanowskich.

Z pozoru pospolite założenie parkowe, z powodu ponad 200 napisów zlokalizowanych na pniach wiekowych drzew, jest już jednak nie tylko przestrzenią rekreacyjną. Stało się miejscem, w którym czytelne ślady zostawiła lokalna historia i często jej anonimowi bohaterowie. Ryty na drzewach pojawiają się w parku także współcześnie, o czym świadczą zidentyfikowane, stosunkowo niedawno wykonane inskrypcje. Park, w wyniku swojego co najmniej stuletniego istnienia stał się więc obszarem palimpsestowym, którego wielowarstwową naturę można dostrzec dzięki dokładnej prospekcji powierzchniowej znajdujących się na jego terenie obiektów przyrodniczych (ryc. 3).

Drzewa ${ }^{4}$ są elementami kreującymi miejsca, na co wskazują autorzy współcześnie prowadzonych badań kulturowych. W przypadku Nakła wykreowane przy użyciu obiektów przyrodniczych założenie parkowe stało się miejscem utrwalania wydarzeń, epizodów biograficznych, swoistym ogrodem pamięci.

Warto zaznaczyć, że ryty na drzewach, jako przedmiot refleksji naukowej, pojawiły się dotychczas w nielicznych polskich opracowaniach dotyczących badań nad dziedzictwem kulturowym. Z uwagi na niewielki zasięg czasowy, obejmujący jedynie okres życia drzew - pozostają głównie w kręgu zainteresowań archeologii współczesności. W nurt ten wpisany jest m.in. tekst Maksymiliana Frąckowiaka, Kornelii Kajdy i Dawida Kobiałki o rytach na drzewach w kontekście wydarzeń II wojny światowej (Kobiałka i in. 2015; 2017). Analizę nadrzewnych inskrypcji w celu rekonstrukcji wydarzeń związanych z konfliktami zbrojnymi przeprowadził również M. Frąckowiak w artykule dotyczącym dziejów fragmentu Międzyrzeckiego Rejonu Umocnionego (Frąckowiak 2009). Wciąż pozostaje jednak poczucie, że temat rytów jest niedostatecznie rozpoznany. Być może wpływ na to ma sam charakter tego typu obiektów dziedzictwa materialnego - dla relatywnie najdokładniejsze-

${ }^{4}$ Drzewa obok wielu innych, są tymi elementami środowiska przyrodniczego, które towarzyszą rodzajowi ludzkiemu od początków jego istnienia. Oprócz aspektu czysto praktycznego - wykorzystania drewna do wzniecenia i podtrzymania ognia, do budowy siedzib mieszkalnych i użytkowych, do wytwarzania przedmiotów codziennego użytku - drzewom, jako obiektom nadano liczne znaczenia symboliczne, kultowe, rytualne. Drzewa, których cykl życia porównywano do przebiegu ludzkiej egzystencji, posiadały znaczącą rolę w wykładniach religijnych, teoriach kosmologicznych i legendach dynastycznych; stanowiąc składową krajobrazu fizycznego, stały się częścią krajobrazu kulturowego. 


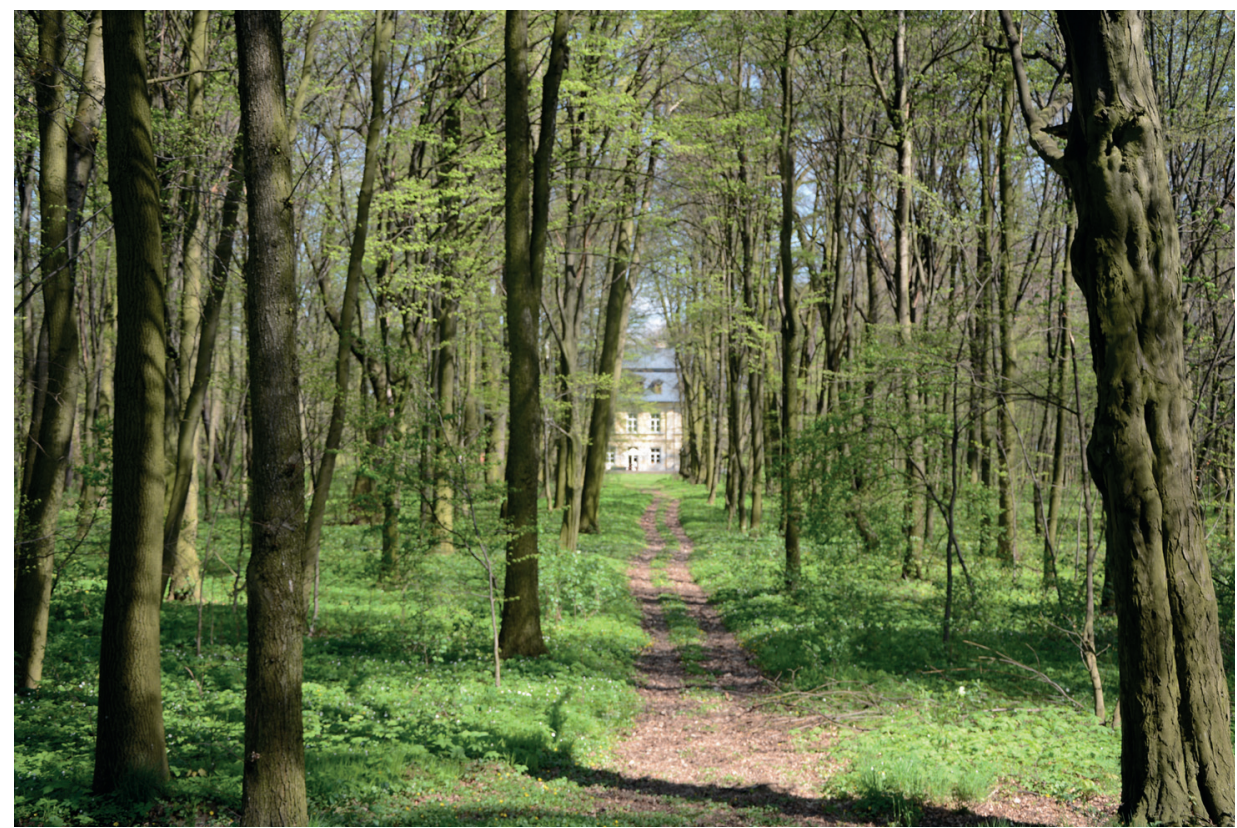

Ryc. 3. Widok na aleję parkową (fot. Aleksandra Krupa-Ławrynowicz, 2016).

go i wiarygodnego opracowania naukowego, poza wnikliwą inwentaryzacją obiektów, z uwagi na odniesienia do niedalekiej przeszłości, często istnieje potrzeba przeprowadzenia również badań terenowych o charakterze etnograficznym, w celu poznania lokalnego, społecznego kontekstu. Niezmiernie istotna jest więc współpraca międzydyscyplinarna. Bez uwzględnienia aspektu etnograficznego, interpretacje zadokumentowanych inskrypcji i przedstawień graficznych biegną wąską ścieżką analizy.

Obiekty stanowiące przedmiot prezentowanego tu komentarza - ryty - wykonano na drzewach znajdujących w położonej na zachód od pałacu części założenia, która charakteryzuje się klasyczną, regularną formą przestrzenną. Główną oś kompozycyjną stanowi stosunkowo szeroka aleja dzieląca park na dwie właściwie komplementarne i symetryczne wobec siebie części, z niewielkim zniekształceniem w części południowej, gdzie wyznaczająca skrajną partię, graniczna ścieżka wykracza łukiem w tym kierunku. Park w swoim obecnym kształcie stanowi kontynuację pierwotnego założenia, również dzięki zmianom dokonanym w ciągu ostatniego dziesięciolecia. Obecni właściciele zlecili zasypanie basenu kąpielowego, który znajdował się u wylotu alei parkowej, tuż przy pałacu (ryc. 4). Obiekt basenowy wiąże się prawdopodobnie $\mathrm{z}$ okresem funkcjonowania w pałacu domu dziecka. Obecnie miejsce jego lo- 


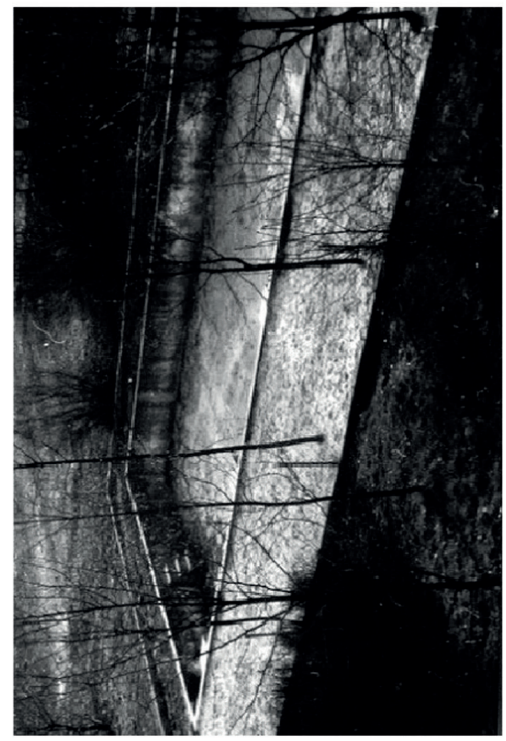

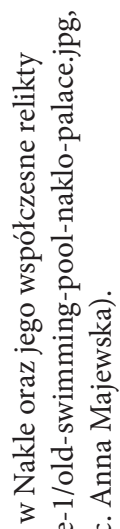

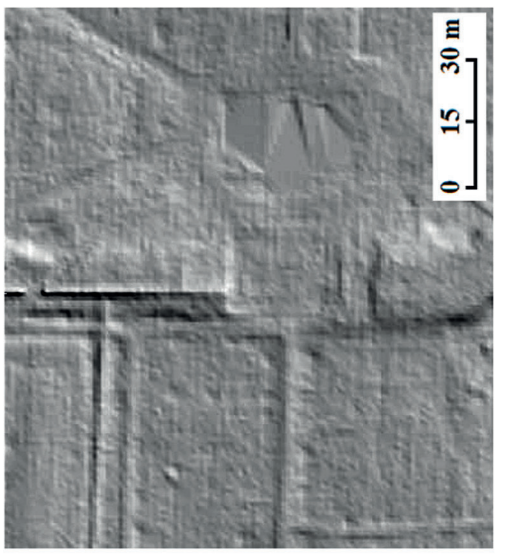

용

赵苋

วิ

冚

क्ष

它苛苛

粦

范范

. 丞

है

霖 $\frac{3}{60}$

$\because 0$

过

㱐

章弯

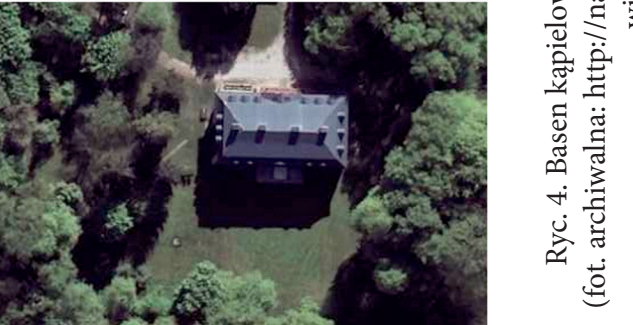



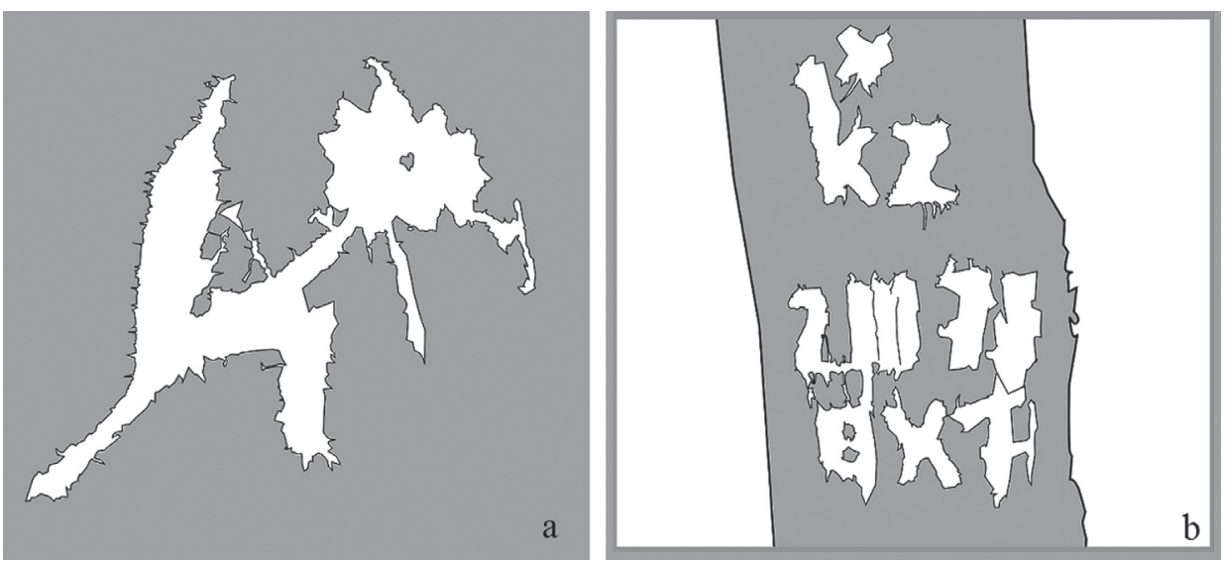

Ryc. 5. Nakło - przykłady rytów (odrysy): a) obrazkowe; b) inskrypcyjne. (oprac. Anna Majewska).

kalizacji jest zupełnie niedostrzegalne $\mathrm{w}$ terenie. Pewne anomalie ukształtowania powierzchni, pozwalające wyznaczyć jego dawne umiejscowienie są natomiast możliwe do identyfikacji na modelu ALS (LiDAR - projekt ISOK). Na podstawie danych z wizualizacji ukształtowania terenu metodą cieniowania można określić przybliżone wymiary obiektu: $20 \times 23 \mathrm{~m}$. Wodę do zbiornika doprowadzał kanał biegnący od północy - jego przebieg jest fragmentarycznie zachowany.

Podczas prowadzenia badań terenowych zidentyfikowano łącznie ponad 200 inskrypcji i przedstawień typu piktograficznego wyrytych w warstwie korowej drzew - głównie buku (fagus silvatica). Ryty związane są przede wszystkim z 33-letnim okresem funkcjonowania w pałacu domu dziecka. Wskazują na to daty (m.in. „1959”, „1966”, „1967”, „1971”, „1974” - ryc. 3), które udało się odczytać z inskrypcji - zostały one zinwentaryzowane $\mathrm{w}$ ramach prowadzenia dokumentacji fotograficzno-opisowej parku w czerwcu 2016 r. Na podstawie analogii udało się w ten sposób w przybliżeniu wydatować ryty nie posiadające oznaczeń liczbowych.

Ze względu na formę epigraficzną rytów wyróżniono przedstawienia:

- obrazkowe (piktograficzne),

- inskrypcyjne (przykłady - ryc. 5).

Większość napisów jest trudnych do odczytania z uwagi na okres czasu, jaki upłynął od ich powstania - od ok. 30 do ok. 60 lat temu. Przez te lata, w następstwie procesów przyrostu pni drzew, pojawiły się liczne zniekształcenia utwo-

\footnotetext{
${ }^{5}$ Napis na 1 m wysokości, wysokość napisu 0,48 m, szerokość 0,54 m.
} 


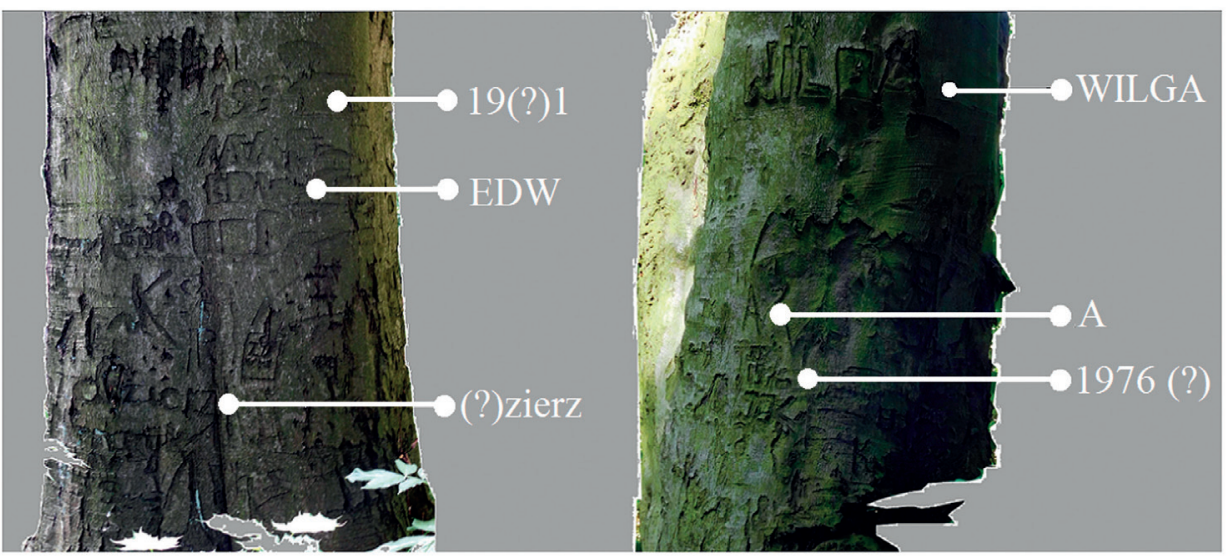

Ryc. 6. Przykłady pni drzew z trudnymi do odczytu, wielokrotnymi, nachodzącymi na siebie formami rytymi (oprac. Anna Majewska).

rzonych form. Problemy w interpretacji sprawiają także ryty, gdzie w obrębie powierzchni korowej drzew nakładają się na siebie inskrypcje i formy piktograficzne pochodzące z różnych okresów czasowych (ryc. 6).

Niektóre z rytów, których treść odczytano, posiadają przypuszczalnie funkcję memoratywną. Stworzone zostały w celu intencjonalnego upamiętnienia jakiegoś wydarzenia, osoby czy relacji międzyludzkiej łączącej twórców tych obiektów. Takim przykładem są pokrewne sobie, umieszczone na dwóch drzewach, przedstawienia zawierające różne inicjały: „K.F.” oraz „M.T.”, ale jedną datę, prawdopodobnie „21 IV 1959” (ryc. 7). Wyryte zostały na wysokości ok. $1 \mathrm{~m}$ od powierzchni gruntu. Inskrypcja zawarta w obrysie serca posiada wymiary ok. 50 × $42 \mathrm{~cm}$. Ryty łączy także sposób przedstawienia: obie inskrypcje zostały ujęte obramieniem. W pierwszym przypadku nadano im kształt przypominający tarczę, w drugim - serca. Nad tarczą wyżłobiono znak swastyki, co jednak nie ma prawdopodobnie związku kompozycyjnego i znaczeniowego z przedstawieniem. Stopień ,rozejścia” się pozostałej części rytu, związany z rozrostem powierzchni korowej jest dużo większy od powyżej przedstawionego symbolu. Tym samym pozwala to wnioskować, że utworzono go znacznie później niż obiekt „tarczy”. Interpretacja obiektów może być bardzo różna. Jedna z możliwości kieruje ku odczytaniu tych form jako wyrazu relacji pomiędzy dwiema osobami, które stworzyły ryty. Mogą one jednakże równie dobrze oznaczać np. datę opuszczenia domu dziecka przez ich wychowanków, pragnących w ten sposób zaznaczyć swoją obecność $\mathrm{w}$ tym miejscu. Odczytanie znaczenia rytów pozostawia więc szeroki margines domniemania. 

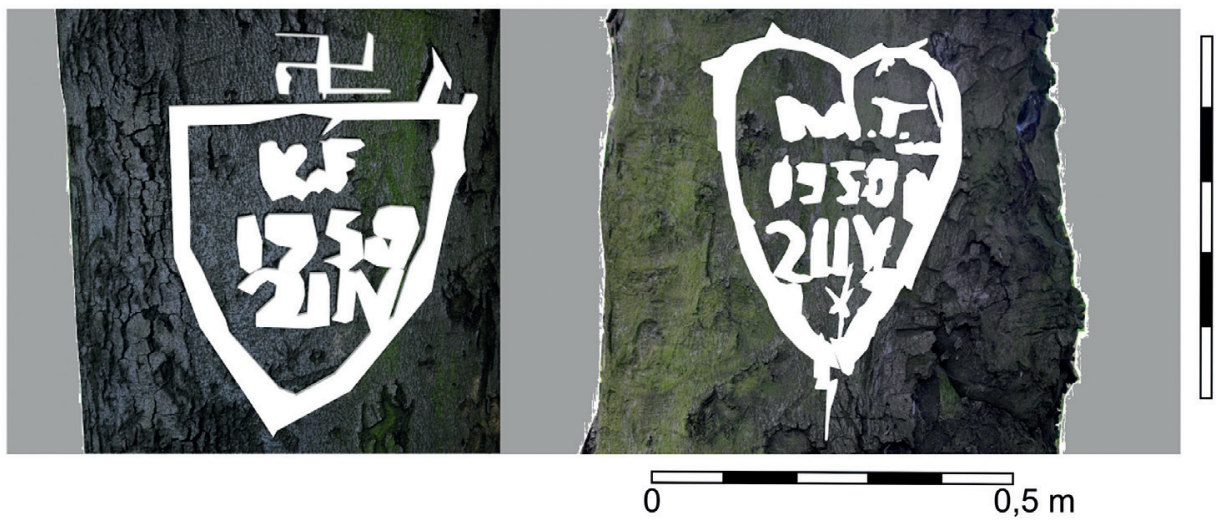

Ryc. 7. Para pokrewnych rytów łączących cechy piktograficzne i inskrypcyjne (w charakterze inicjałów i wyrażeń liczbowych) umieszczone na osobnych drzewach (oprac. Anna Majewska).

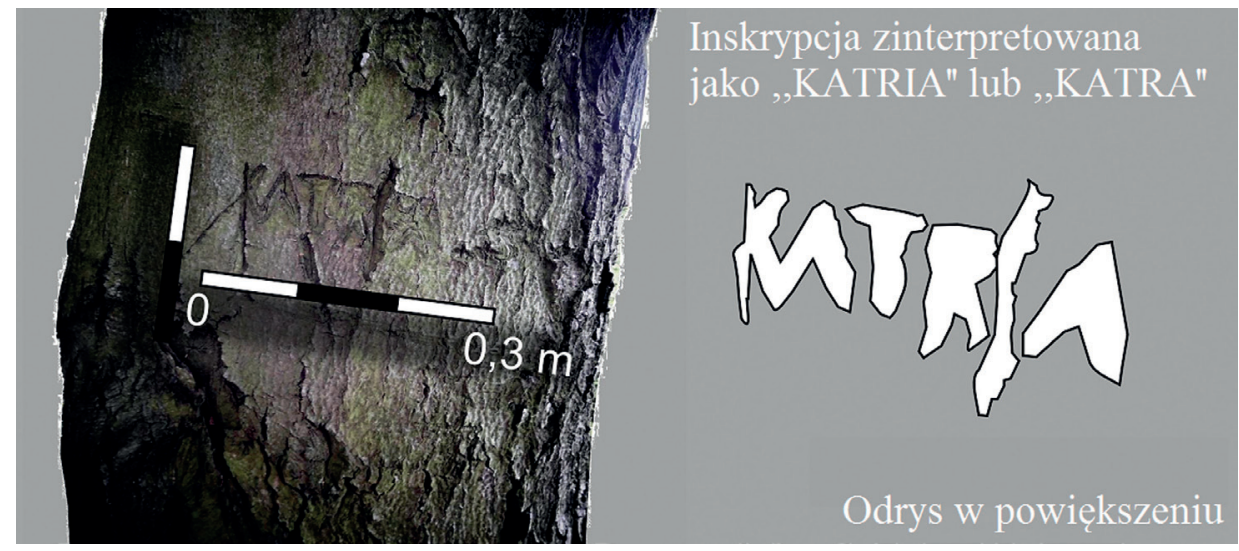

Ryc. 8. Ryt - przykład inskrypcji imiennej (oprac. Anna Majewska).

Wiele rytów znajdujących się w nakielskim parku pałacowym ma charakter inskrypcji imiennych. Jednym ze zidentyfikowanych jest napis „Katria” lub „Katra" umieszczony na wysokości 1,3 m (ryc. 8). Inne imienne to: „ADA”, „Lotta”, „JOLA”, „STEFAN”. Pojawiają się liczne inicjały/skróty. Oprócz już wymienianych są nimi m.in.: „SS”, „WP”, „MD”, „ZS”, „,kz”, „AS”, „JS”. Występują także pełne imiona i nazwiska, np.:

\footnotetext{
${ }^{6}$ Napis znajduje się na wysokości ok. 1,32 m. Długość napisu wynosi 0,2 m.
} 
- „Nowak Henryk 1968” (lub 1965) (napis znajduje się na wysokości $1,25 \mathrm{~m}$, szerokość $0,4 \mathrm{~m}$, wysokość $0,4 \mathrm{~m}$ ),

- „TADEUSZ CZEPNIK” (napis znajduje się na wysokości 0,76 m, szerokość ok. 0,28 m, wysokość $0,21 \mathrm{~m}$ ).

Historia pałacu i parku w Nakle przepełniona jest pamięcią indywidualną i zbiorową, mającą wiele obliczy, zawierającą mnóstwo doznań, odczuć i emocji - niekiedy sprzecznych, czasem przeinaczonych. Pałac i jego zmieniający się właściciele, pracownicy, stali goście, sąsiedzi niejako konstytuują się wzajemnie. Posiadłość staje się więc - w różnym stopniu i natężeniu - miejscem w znaczeniu antropologicznym, czyli fragmentem świata obdarzonym sensem i wartością, związanym z doświadczeniem codzienności zarówno konceptualnie, jak i bezpośrednio. Przychodzi tu na myśl współczesna wykładnia miejsca jako przestrzeni uczłowieczonej, uwzględniająca przede wszystkim człowieka w kontekście lokalnym, istotę ludzką posiadającą zapisane i zakodowane forpoczty przestrzenne, czyli właśnie miejsca, do których przynależy ${ }^{7}$. Przywołać warto także tradycje egzystencjalno-fenomenologiczne, ujmujące relacje miejsce - człowiek we wzajemnym współistnieniu i współformowaniu. Doświadczanie miejsc zatem, a potem sposób ich opisu wymaga odwoływania się do różnych poziomów narracji. Nawiązując do Martina Heideggera, ważniejsze niż samo miejsce w swej fizyczności jest znaczenie bycia w miejscu, wynikające z ludzkiej z nim koegzystencji. Perspektywa Heideggerowskiej analizy egzystencjalnej każe widzieć więcej niż współrzędne geograficzne, ujmując stosunek człowieka do miejsca w kategoriach relacji duchowej, wynikającej z subiektywności i bezpośredniości doświadczeń. Miejsce w przywołanych tu koncepcjach staje się obszarem specyficznie ludzkiego zaangażowania, kształtowanego na zasadach „czasowego wzoru”. Z kulturowego punktu widzenia są to przestrzenie znaczące dla konkretnych jednostek i wspólnot. Wiąże się z nimi system wiedzy, wyobrażeń i wartości oraz reguł zachowania, dzięki którym zachodzi proces identyfikacji i integracji społecznej.

Park przypałacowy jako miejsce, to nie tylko tkanka materialna, historyczne zdarzenia, to także aktywizacja pamięci, przesądzająca o wielowarstwowości i wielogłosowości tego miejsca; to połączenie różnych poziomów sensu, konstruowanych i odczytywanych na gruncie rozmaitych kompetencji, rozpoznawanych przez wtajemniczonych $\mathrm{w}$ proces rozszyfrowywania wielopoziomowych relacji znaczeniowych; skomplikowanej konstelacji, na którą składają się pamięć, przestrzeń i doświadczenie.

${ }^{7}$ Edward Relph rozpoczyna swoje studium poświęcone miejscu i jego braku od znaczącego stwierdzenia, że „być człowiekiem, to mieć i znać swoje miejsce” (Relph 1976: 5). O miejscu w znaczeniu humanistycznym pisał także Yi-Fu Tuan (Tuan 1987). 
Ryty jako formy kultury materialnej stanowią cenne elementy w procesach rekonstrukcji wydarzeń z przeszłości. Ich odczytanie i interpretacja są istotne przy uzupełnianiu stanu wiedzy na temat miejsc i związanych z nimi osób. Niczym zapominane historie, ryty również po jakimś czasie tracą swą czytelność, pozostając dziedzictwem trudno uchwytnym i jak życie przemijalnym. Dlatego warto je zauważać, analizować i przywracać o nich pamięć, tym bardziej, że ukazują niewymuszoną, rządzącą się potrzebą chwili, a pozostawiającą historyczną ciągłość korespondencję kultury z naturą.

Ewa Rewers pisząc o mechanizmach pamięci w relacji do przestrzeni, twierdzi, że szczególnie istotne są trzy jej rodzaje. Wylicza pamięć polityczną, intelektualną i potoczną (Rewers 2005). W kontekście pierwszej z wymienionych, nakielski kompleks pałacowo-parkowy funkcjonuje jako swoisty pomnik historii i idei. Pamięć intelektualna z kolei, odnosiłaby się do takich uczuć jak tęsknota, marzenie, do postawy kontemplatywnej, zależnej od indywidualnej recepcji. Pamięć potoczna natomiast konstytuowałaby park, jego alejki, zabudowania pałacowe jako miejsce prozaiczne, codzienne - miejsce mijane, wpisane trwale w powszedniość, oczywiste.

W odtwarzaniu i w konstruowaniu miejsca antropologicznego najważniejsze są zatem znaczenia, poprzez które się je odczytuje i opisuje. Te znaczenia - wytwarzane i nadawane przez dawnych i obecnych, stałych i tymczasowych użytkowników - wpływają też na ich samookreślenie. Inaczej o nakielskich dobrach opowiada przecież kronikarz dawnych jej dziejów, a inaczej spadkobierca rodzinnej pamięci; inne doświadczenia przypisane są mieszkańcom, inne pracownikom majątku. Nie bez znaczenia są również, wyróżnione przez Edwarda Relpha: wewnętrzność i zewnętrzność wobec miejsca, które mogą się wzajemnie przenikać, budując wielogłosową narrację o pałacu w Nakle (Relph 1976). Patrząc od wewnątrz, możemy bowiem przyglądać się znaczeniom dzielonym przez wspólnotę miejsca, przekazywanym przez pokolenia tradycjom i narastającym opowieściom, przechowującym pamięć danego miejsca, ludzi i zdarzeń, które często nie są pozbawione mitycznego charakteru i nostalgicznych zabarwień. Opisywanie pałacu z zewnątrz pełne jest gotowych charakterystyk, uproszczeń i utartych schematów.

Miejsce, najczęściej lokowane w krajobrazie fizycznym, jest jednocześnie elementem krajobrazu kulturowego, rozumianego w kontekście estetycznym, percepcyjnym, ideologicznym i pamięciowym. Idąc za myślą Williama J.T. Mitchella, przekonującą, że krajobraz nie jest neutralnym pojęciem, ale ,instrumentem władzy kulturowej, a czasem nawet jej czynnikiem sprawczym" (2002: 1-2), miejsce także może być konstruktem ideologicznym, staje się wówczas polem walki o znaczenia określonych grup. Na rolę krajobrazów ideologicznych, naładowanych afektywnymi i symbolicznymi znaczeniami w tworzeniu tożsamości ich użytkowników, wskazuje też między innymi Tim Edensor 
(2004). Krajobraz jest jednak równie często traktowany jako miejsce pamięci lub mnemotopos. W ten sposób krajobraz i jego elementy - w opisywanym przykładzie jest to nakielski majątek - stają się topograficznym palimpsestem pamięci kulturowej, w którym nawarstwiają się kolejne pokłady pozostałości ludzkich działań. Te materialne ślady mają oczywiście, jak zauważa Karl Schlögel, wielu autorów i pisane są w różnych językach (Schlögel 2009: 283). Ponadto w równie ważnej perspektywie performatywnej, krajobraz jest traktowany nie tyle jako obiekt ludzkich działań, ile jako czynnik sprawczy, który może wpływać na ludzką historię i kształtować ją. Taki punkt widzenia proponuje na przykład W.J.T. Mitchell, gdy deklaruje, że: „Krajobraz nie będzie więc tylko przedmiotem estetycznej kontemplacji lub tekstem do czytania, lecz także procesem, który formuje społeczne oraz jednostkowe tożsamości” (2002: 1). W.J.T. Mitchell zatem nie zadaje pytań o to, czym krajobraz jest lub co znaczy, lecz co krajobraz i lokowane w nim miejsca czynią, w jaki sposób działają jako kulturowa praktyka. To oddziaływanie dotyczy oczywiście najczęściej sfery emocji i znaczeń.

W odtwarzaniu miejsca - nieustannie pojmowanego tu jako fragment przestrzeni pełen znaczeń - niekiedy należy podejmować więc próbę przywołania posiadłości nakielskiej już nieistniejącej, nie do rozpoznania w jej obecnym kształcie, nie do wyczytania ze współczesnej mapy, miejsca zapamiętanego, często przetworzonego. Co za tym idzie, trzeba poszukać, by owe znaczenia odnaleźć i zrozumieć. Wpisane są one w cechy przestrzenne, w historię rodziny Bystrzanowskich i Komorowskich, we wspomnienia mieszkańców Nakła pracujących w majątku, w opowieści o wojennej trwodze i ukrywanej w pałacu broni, czy też właśnie w napisy wyryte w korze parkowych drzew przez na przykład mieszkańców funkcjonującego tu domu dziecka.

Nie jest to jednak sztuczna, uporczywa rekonstrukcja odwołująca się do imaginacyjnej nostalgii. Pałac w Nakle, drzewa w przypałacowym parku - sposoby ich funkcjonowania, opisywania, rozumienia - wpisują się w rytm historii, w realia życia codziennego, w proces budowania i niszczenia. Można je rozpoznać jedynie wówczas, gdy przyjmiemy, iż trwanie polega na nakładaniu się na siebie kolejnych warstw kulturowych przy ich jednoczesnym połączeniu.

Pałac wraz z opisywanym parkiem jest zatem miejscem antropologicznym w procesie; miejscem ciągle konstruowanym i negocjowanym, cechującym się nieustanną potencjalnością puenty i stanem wiecznej gotowości. Posiadłość zmienia się, inaczej wyglądają jej wnętrza, inne prowadzi się w niej rozmowy. Zmieniają się też jej mieszkańcy, pracę wykonuje pamięć - indywidualna i zbiorowa. Nowi właściciele próbują prowadzić dialog pomiędzy przeszłością i teraźniejszością, a także wizją przyszłości miejsca; pomiędzy chęcią odtworzenia historii pałacu i propozycją dedykowania mu nowych funkcji. W swoich codziennych praktykach użytkownicy tej przestrzeni wciąż na nowo potwier- 
dzają jednak swój adres. Park otaczający pałac jest dla nich miejscem znajomym, tematem sąsiedzkich pogawędek, wiąże się z nieuchwytnym poczuciem przebywania na swoim miejscu - wiele nagromadzonych czynników oraz ich kombinacja sprawiają, że przestrzeń posiadłości „staje się nie tylko przedmiotem poznania, ale także miejscem uznania" (de Certeau i in. 2011: 9).

Praca naukowa finansowana $\mathrm{w}$ ramach programu Ministra Nauki i Szkolnictwa Wyższego pod nazwą Narodowy Program Rozwoju Humanistyki w latach 2014-2019.

\author{
Aleksandra Krupa-Ławrynowicz \\ Instytut Etnologii i Antropologii Kulturowej \\ Uniwersytet Łódzki \\ ul. Lindleya $3 / 5$ \\ 90-131 Łódź \\ e-mail: aleksandra.lawrynowicz@uni.lodz.pl \\ Anna Majewska \\ Studentka archeologii Uniwersytetu Łódzkiego \\ ul. Narutowicza 65 \\ 90-131 Łódź \\ e-mail: anna.majewska@op.pl
}

\title{
Bibliografia
}

de Certeau M., Giard L., Mayol P. (2011), Wynaleźć codzienność, t. 2, Mieszkać, gotować, przeł. K. Thiel-Jańczuk, Wydawnictwo Uniwersytetu Jagiellońskiego, Kraków.

Edensor T. (2004), Tożsamość narodowa, kultura popularna i życie codzienne, przeł. A. Sadza, Wydawnictwo Uniwersytetu Jagiellońskiego, Kraków.

Frąckowiak M. (2009), Historia na drzewach zapisana. Przyczynek do poznania dziejów MRU na podstawie napisów zachowanych na bukach w poblizu Chyciny, [w:] B. Mykietów, M. Tureczek (red.), Ziemia Międzyrzecka w przeszłości, t. 7, Muzeum w Międzyrzeczu, Międzyrzecz, s. 143-150.

Kobiałka D., Frąckowiak M., Kajda K. (2015), Tree memories of the Second World War: a case study of common beeches from Chycina, Poland, „Antiquity”, t. 89(345), s. 683-696.

Kobiałka D., Kajda K., Frąckowiak M. (2017), Wspomnienia drzew, „Archeologia Żywa", t. 3(65), s. 48-51.

Matysiak M. (2003), Organizacja i formy duszpasterstwa parafii Nakło k/ Włoszczowy od chwili erekcji do roku 2002, http://www.naklo.kielce.opoka.org.pl/historia parafii/historia_parafii.htm\#_Toc36908262 (dostęp: 20.03.2018).

Mitchell W.J.T. (2002), Landscape and Power, University of Chicago Press, Chicago.

Relph E. (1976), Place and Placelessness, Pion, London. 
Rewers E. (2005), Post-polis. Wstęp do filozofii ponowoczesnego miasta, Universitas, Kraków.

Schlögel K. (2009), W przestrzeni czas czytamy. O historii cywilizacji i geopolityce, przeł. I. Drozdowska, Wydawnictwo Poznańskie, Poznań.

Trela S. (2005), O starej wsi Nakło i współczesnym jej rozwoju, Nakło (praca nieopublikowana).

Tuan Y. (1987), Przestrzeń i miejsce, przeł. A. Morawińska, Państwowy Instytut Wydawniczy, Warszawa.

\section{Źródła internetowe}

Geoportal.gov.pl: www.geoportal.gov.pl (dostęp: 20.03.2017).

Oficjalna strona Fundacji Nakielskiej: http:/naklopalace.org/pl/fundacja-nakielska/ (20.03.2017).

Oficjalna strona Pałacu w Nakle: http://naklopalace.org/pl/ (dostęp: 20.03.2017).

Oficjalna strona projektu badawczego Miejsca pamięci i zapomnienia. Badania interdyscyplinarne pólnocnych terenów Jury Krakowsko-Częstochowskiej: http://najurze.uni.lodz.pl/ (dostęp: 20.03.2017).

Rejestr zabytków nieruchomych woj. śląskiego. Narodowy Instytut Dziedzictwa: http:// www.nid.pl/pl/Informacje_ogolne/Zabytki_w_Polsce/rejestr-zabytkow/zestawienia-zabytkow-nieruchomych/ (dostęp: 20.03.2017).

\section{SUMMARY}

\section{QUOTES FROM THE PAST - CARVINGS ON TREES \\ IN THE NAKŁO PALATIAL GARDEN (LELÓW COMMUNE). READING THE UNOBVIOUS ELEMENTS OF THE LOCAL HISTORY}

The palace and park in Nakło were built by Count Kajetan Bystrzanowski in the years 1770-1780. After his death the property was passing from hand to hand, to finally get to the Komorowski family (Matilda, the wife of the successor to the throne of Belgium and Franciszek Starowieyski, a painter, belong to this family). Komorowski managed the assets until the end of The Second World War but then he lost them to the state. For several years, the palace housed an agricultural, technical school and later - to 1989 - an orphanage. Since 2002, Marzenna and Kerth Reyher have been the owners of the building.

The theme of the article are the stories, memory and community importance of the palace in Nakło, forming a part of the physical and cultural landscape of the Lelów municipality. The authors show the local narratives which were collected during the ethnographic research on the places especially important for the Lelów community, which are the witnesses and traces of the past. Another aim of the article is to discuss 
the issues of carvings on trees - forms of material culture that are valuable elements in the processes of reconstructing the events from the past. Their reading and interpretation is important in supplementing the state of knowledge about the places and people associated with them, who left carvings on the trees. Like forgotten stories, carvings also lose their legibility with time, yet remaining a legacy that is difficult to grasp and is transient just like life is. Therefore, it is worth noting while analyzing and restoring the memory about them, the more so as they show the unforced, governing need of the moment, and leaving the historical continuity of correspondence between culture and nature.

The palace and park is treated as a place in the anthropological meaning and as an element of the landscape understood in the context of aesthetics, perception, memory and ideology. 